\title{
Social enterprise scaling up strategy - franchise development
}

\begin{abstract}
Marta Ziótkowska*
This paper is an exploratory study on the essence of social franchise as a business model and form of entrepreneurship and study how to use the proven business model to satisfy social needs. The paper is descriptive in nature and case study research approach has been used. The paper examines social franchising by analysing and exploring case studies of social enterprises. The study's findings prove that franchise may be successfully applied in different dimensions of social entrepreneurship. It is concluded that the franchise model can be used as a tool to build socially sustainable societies and help to resolve the problem of social exclusion. Moreover, the study provides basic characteristics and knowledge for future in-depth research with regards to this topic.
\end{abstract}

Keywords: social enterprise, social business, business model, social entrepreneurship, franchise, franchising.

Submitted: 11.05 .17 | Accepted: 28.01.18

\section{Strategia skalowania przedsiębiorstwa społecznego - rozwój franczyzy}

Artykut ma charakter studium nad istota franczyzy spotecznej jako modelu biznesu i formy przedsiębiorczości oraz analizy, w jaki sposób wykorzystywać sprawdzony model biznesu do zaspokojenia potrzeb spotecznych. Wykorzystano metode opisowa oraz analize studiów przypadku. W artykule dokonano analizy franczyzy społecznej przez eksploracje studiów przypadków przedsiębiorstw spotecznych. Wyniki analizy potwierdzaja, że franczyza może być implementowana $z$ sukcesem $w$ różnych wymiarach przedsiębiorczości spotecznej. Wywnioskowano, iż model franczyzy może zostać użyty jako narzędzie do budowy spoteczności spotecznie zrównoważonych i umożliwiać rozwiązywanie problemów wykluczenia społecznego. Ponadto $w$ artykule przedstawiono podstawowe zatożenia $i$ wiedzę mogaca stużyć dalszym pogtębionym badaniom $w$ odniesieniu do zaprezentowanej tematyki.

Słowa kluczowe: przedsiębiorstwo społeczne, społeczny biznes, model biznesu, przedsiębiorczość społeczna, franczyza.

Nadesłany: 11.05.17 | Zaakceptowany do druku: 28.01.18

JEL: L26

\footnotetext{
Marta Ziółkowska, PhD - Institute of Management, Warsaw School of Management.

Correspondence address: Institute of Management, Warsaw School of Management, Al. Niepodległości 162, 02-554 Warsaw, Poland; e-mail: mziolkow@sgh.waw.pl.
} 


\section{Introduction}

Many organisations operate with a mission statement that matches their goals and ideals. Some firms seek to increase their financial success and profit, while others demonstrate benevolence to the world by serving as non-profit organisations. However, there are merely a few that choose to combine the two factors in order to create a company that not only achieves financial success but also adds value to the world One alternative for scaling up social impact fostering growth beyond the confines of the organization is social franchise (Lyon and Fernandez, 2012). The business model that can be used to help solve social problems is social franchise, which involves the application of business-format franchise (commercial franchise) to achieve social benefits. Consequently, there is limited knowledge about social franchising within the ecosystem of social enterprises. Despite the increasing popularity of social franchising to scale up and replicate a given business model, there has been little research on this topic. The aim of the paper is to deepen the knowledge of social franchising and examine successful franchisors case studies to examine how to use the established franchise method of doing business, translating and transforming it into a social attitude. This paper seeks to examine the strategies social enterprises can use to scale up their impact. A traditional view has been for growth to occur through expanding knowledge of social franchise model of doing business.

The paper is based on an analysis of three detailed case studies of social enterprises which uses franchise to scale up its operations. These were selected purposefully to represent franchise method of cooperation.

This paper addresses the gap in the current literature and research by presenting business models using social franchise to satisfy social needs in the economy ${ }^{1}$. Social franchising has been utilised by the third sector in a variety of ways, yet franchising as a form of social entrepreneurship constitutes a new area of research. There is a need for better understanding of the basics of the phenomenon and for clarification of its fundamental meaning. The author would like to focus strictly on social franchising as an organisational form.

\section{Notion of the franchise social business model}

Basically, social franchising is an adaptation of commercial franchising in which the developer of a successful social concept (franchisor) enables others (franchisees) to replicate the model using a proven system and a brand name to achieve a social benefit. Social franchising can be defined as a system of contractual relationships which uses the structure of a commercial franchise to achieve social goals (Tracey and Jarvis, 2007). Social franchise emerges with the objective to make a social impact by tackling crucial social issues such as unemployment, social exclusion of groups, poverty, social cohesion, environment protection, health, and education. Practitioners on this market refer to social enterprises as 'profit-making, not profit-taking' (Du Toit, 2014, p. 12). Thus, social franchising is a suitable scaling strategy for some social entrepreneurship companies but not for others (Beckmann and Zeyen, 2014). Nonetheless, franchising can represent an effective approach to mastering the complexities to replicate a proven concept (Volery and Hackl, 2010), as it happens in the commercial franchise business model.

Nevertheless, social franchise is the use of a commercial franchising approach to replicate and share proven organisational model for greater social impact, at the same time maintaining quality and productivity schemes based on the standardization that are present in all franchises.

The use of franchising to solve social problems is based on the essential feature of that kind of business - replication. Social franchise facilitates better business performance to fulfil social needs. Schuhen (2004, p. 156-157) suggests a more functional definition: "Social Franchising is the non-profit form of vertical or horizontal cooperation with the aim of replicating social programmes and services as well as governing and linking social organisations". Consequently, social franchising must be also considered as a form of cooperation between equal partners. As such, social franchising is also a matter of cultivating a partnership, joining forces and benefiting from membership in cooperative organisations. More specifically, social franchising can be understood as contract-based cooperation of decentralised entrepreneurial 
units with a central support unit, uniform quality standards and support of a common philosophy (Braun and Lotter, 2004, p. 9).

It is crucial to analyse the sources of financing. Social franchise is related to social or commercial projects. This is how SMEs can expand the production or marketing of their goods or services among their employees or external professionals who do not have the resources to buy a franchise. It is about taking advantage of the individual's ability to generate results, compensating for their lack of financia capital with the contribution of intangible assets (knowledge, entrepreneurship, experience, intellectual and social capital). Social franchise contributes to satisfying social needs, maintaining quality and productivity. The moral value of a cause adds the strategic value of mobilizing resources towards the public good, making philanthropy an agency of social change rather than a business for those who administer it. Social franchising is primarily a method for transferring knowledge from one established social enterprise to another that wants to achieve the same social and financial goals.

With social franchising, there may be complications with replicating the idea successfully. When implementing social franchise, it is important to find a franchisee that shares the same values as the franchisor. They should understand the business (Cook, 2012). It is important to define who can be a franchisee. An appropriate person must display such qualities as flexibility and an entrepreneurial spirit, they must be willing to share franchisor's values according to the manual and represent social engagement.

Potential social franchise formats range from commercial franchises with intended social effects to non-profit replication systems with franchising elements. Three formats can be identified in principle. The first one is a commercially organised franchise system for achieving social benefits. The sole difference between commercial franchising is the focus of the system as a whole on social benefits and the absence of the primary goal of generating profit for private individuals. The second format consists of a subsidized franchise system to make services available at lower cost than commercial solutions. This may include profit-making entrepreneurs at the fran- chisee level. The final one is a non-profit replication system which includes the core elements of franchising, but without the classical fee and profit elements.

\section{Social franchise business model - case studies}

The exploratory case study approach was adopted to collect data. This research method is ideal to investigate the social franchise phenomenon when available research or an existing knowledge base is limited (Yin, 2003). Thus, it provides a rich and holistic analysis, which is extremely useful in revealing complexity and dynamism of the subject matter. This present study was designed as a multiple-case study describing three purposely selected social franchises (Care and Share Associates, Community Food Centres Canada, CAP-Märkte). The data was collected from desk research to analyse social franchising through the case study approach. Gathered documents included franchise agreements, online materials, newspaper clippings, and magazine articles. There is no quantitative evaluation on this topic available yet, due to the small number of existing social franchises. A thorough study of social franchise concepts leads to better understanding of the idea and determinants of a given business model supporting the development of social value.

\section{Care and Share Associates- health and social care}

The first interesting case study is CASA, which was established in 2004 to offer support services to elderly and disabled people. They based their social franchise on the Sunderland Home Care Associates model that has been providing quality domiciliary support since 1994 (European Social Franchising Network, 2011). The Sunderland Model was founded by Margaret Elliot, who also founded CASA. CASA has 850 employees who provide 18.000 hours of care every week. Since their establishment, CASA has developed five franchise companies, operating across eight territories. This makes them the leading social enterprise in the social care sector in the United Kingdom. They are headquartered in Newcastle Upon Tyne. Their main customer is the public sector. 
Since the main goal of social franchising is not pure profits, some franchisors find it difficult to be self-financed. They can be sponsored by an NGO or get charitable donations, to keep going. However, as the business develops, many of them aim at becoming self-sustainable. In its early stages, CASA got core funding from European EQUAL-funded project INSPIRE. CASA is now completely self-financed. They get a $4,2 \%$ royalty or licence turnoverfee when their franchise companies reach break-even.

Each new business requires an initial investment of $€ 175.000$ from local funders, and commitment from the local authority to purchase a specified number of hours once the company is established. Furthermore, to buy a new franchise, one needs to have some previous care management experience.

When a new CASA franchise company is established, CASA provides the following services:

- Preparation of a Business Plan

- Registration with the Care Quality Commission

- Company incorporation, including Employee Benefit Trust

- Criminal Records Bureau checks

- Access to approved providers list

- Advertising and staff recruitment, a staff induction programme

- Access and right to use the CASA Business Manual.

Successful factors can be enumerated as follows:

- Identification and securing appropriate premises

- Corporate design, uniforms etc.

- Securing start-up funding

- Website

- Financial management, company administration and pay-roll

- Human resources and training

- Marketing and contracting

- Product innovation and development. There is a very good ratio of investment to revenues. For all their franchises, the average revenue is around $€ 600.000$. In comparison to the investment, it is quite high. It gives economic stability as the cost structure is relatively simple. With the cost structure that does not require a lot of inventory or stock, it is easier to secure the franchisee. In case of an economic or social downturn, it is easier to get out of a given franchise without losing too much money. This is primarily a service company, which means that the company mainly operates with intangible assets - people, knowledge and care.

Taking the above into account, the potential risk of opening this franchise is scored between low to medium risk venture, provided a new franchise is opened within the UK. CASA is somehow both a new and old company, since it dates back to 1994 , but was established in 2004. It has had some years to test the business model but still it is adapted to the recent market. Furthermore, they have increased their business rapidly and are now operating in eight territories. Their mission fits well with the societal problems in the UK which is their base. This offers good market opportunities. Lastly, the initial investment is a great amount of money, but in comparison to the average turnover, the investment can be earned back within first years.

CASA's slogan is "We believe in people before profit" and this is an essential value for the company. Its profit gets reinvested to improve the quality and company's performance. There might be a risk connected with this as a given franchisee might want to be an entrepreneur and earn money more than care for the value statement. CASA does a lot to avoid this and choose the right franchisees, but still it should be considered to be a risk.

Since this franchise currently operates only in the UK, opening a franchise outside the UK on a new market would mean higher risk. The business model is based in the UK and takes into account its regulations and system. Even though it is a successful franchise in the UK, there is no guaranteed success on another market, even if it were similar.

There is a demand for private services in the UK. According to statistics, $11 \%$ of the population prefer to pay for private health insurance (The Guardian, 2016). CASA has already expanded to eight territories, but with $11 \%$ of customers preferring private companies, there could still be a market for more franchises. The UK spends less of their GDP on healthcare than, for example, Germany and France, and with the increasing elderly demographic, CASA might have good prerequisites for increasing their market share. 


\section{Community Food Centres Canada - food-focused organisation}

The next example of a successful social franchise business model is Community Food Centres Canada (CFCC). This is a non-profit organisation that works to combat food and health related issues within low-income communities across Canada. Toronto-based CFCC provides ideas, resources and a proven model to partner organisations across the country. The partner organisations, which effectively operate as "franchisees" in the model, then establish reactive and well-resourced community food centres (CFCs). These food centres work to empower communities and bring their residents together so that they can learn how to grow, cook, and share 'good food'. CFCC has a structured criteria and selection process that each interested organisation is fitted against. Potential partnerships are assessed on an ongoing basis, however, a maximum of three are admitted per year. According to its 2015 Annual Report, CFCC funding is acquired from four sources: the government, corporations, major donors, and family and granting foundations.

While CFCC doesn't market itself as a social franchise, it is organised with the same defining characteristics of a social franchise, with CFCC acting as the franchisor and a given Partner Organisation acting as the franchisee. The defining characteristics include a legal agreement, ongoing obligations between both parties, the replication of brand and operations, a territorial operations strategy, and financial obligations of the franchisor towards the franchisee.

The framework for CFCs is based on the operation of three core programmes: Food Access, Food Skills, and Education \& Engagement. After the model was established, CFCC began a pilot project with two partner organisations in Perth and Stratford, Ontario. This step was critical in allowing CFCC to improve and mature its food centre concept while mitigating premature expansion. Both pilot partnerships were successful. The organisation's goal is to develop 10-12 CFCs with partners across Canada by the end of 2017.

A fundamental component of the organisation's framework is the partnership criteria and selection process CFCC utilizes to develop a CFC. The criteria, which are publicly available on the CFCC website, include the following:

- The organisation has its own board and charitable status.

- The organisation has existing, trusting relationships with members of lowincome communities, and would be able to offer CFC programming that is targeted at low-income communities (roughly $80 \%$ or more participants served are low-income, established by means other than means-testing).

- The organisation can cater for community needs and provide support (not duplicating other local initiatives, no significant risks or opposition).

- The organisation embraces the shared Community Food Centre vision, strategic objectives and principles, and can demonstrate that the board, senior staff and other key stakeholders are supportive of the organisation's mission.

- The organisation has or can secure the physical space required for programmes, including a commercial kitchen, dining/ meeting space, offices, and a nearby garden.

- The organisation has staff infrastructure that is (or could be, with added CFC resources) robust enough to support the project.

- The organisation operates in a community that can sustain a CFC (likely a midsize to major city, though there may be exceptions to this rule).

- The organisation has a track record of visionary, effective leadership.

CFCC uses these criteria as a general guideline for requirements, but states that it can be flexible on some elements depending on the balance of other factors. For example, the possession of a non-capital-intensive physical site is noted as a very beneficial asset to the partnership. In addition to making organisations define their interest in managing a CFC, CFCC also researches areas where they would like to operate and uses key community informants to search for and pursue partnerships.

For a new partnership and CFC project to be taken on, it requires cooperation and coordination of various functions. The first one is commitment to programmes in accordance with the model. Each CFC is to be focused on the development of programmes in 3 areas: food access, food 
skills, and education \& engagement. The partner organisation must be willing and dedicated to representing these programme areas. Specific elements include offering a healthy food bank, community meals and gardens, and developing public education programmes and policy campaigns regarding food and hunger issues. Secondly, providing in-kind support, willingness and ability to assign non-cash resources to a given $\mathrm{CFC}$ constitutes an integral responsibility of the partner organisation. CFCC expects its partners to provide in-kind support proportionately to its organisational size and capacity. In-kind support may include integrating existing staff, equipment and furniture, or sourcing bookkeeping or fundraising services. Next, organising ongoing evaluation through identification and report on the collective short, medium and long-term impacts CFCs have across communities in Canada is a key to CFCC's approach. To measure and demonstrate this impact, trigger continuous improvement, and maximise social impact, partner organisations are required to implement the evaluation framework that CFCC equips them with. Regardless of the pre-existing brand recognition an organisation brings to the partnership, it is required to adopt the Community Food Centre identity, and to brand its centre as such. This is expected, considering that a common brand is an integral component of the social franchise model, and CFCC provides each organisation with the marketing materials to meet the requirement. Capacity-building and fundraising is also an important issue. While specific financial obligations depend on the partner organisation's capacity and/or the needs of the targeted community, it must be willing to develop long-term financial sustainability. This is achieved by working with CFCC to develop and implement the necessary capacity-building and/or fundraising structure for CFC long-term operations.

According to available annual reports of CFCCs (CFCCa) in operation, partner organisations receive a significant amount of funding from CFCC itself. For example, The Table CFC reported \$616,717 CAD in income in 2015, \$166,514 CAD (27\%) of which was from CFCC. Other contributors included in-kind food donations, foundations, government, businesses, events, individuals, and other organisations. Addition- ally, Dartmouth CFC reported receiving a total of $\$ 684,340$ in 2015 from CFCC for developing its new CFC and its programming.

The next important issue is engagement. With a long-term perspective in mind, each partner organisation must be prepared to enter into a collaborative engagement, planning and decision-making framework with CFCC. This requirement is critical to the alignment of the parties' values, goals and expectations, and involves regular meetings and a programme development process. Although CFCC does not explicitly state that they provide an operations manual, providing ample and ongoing support (i.e. training and resources) is evidently critical to its model.

From the perspective of CFCC, the 'franchisor', there is a relatively high risk in the investment in and dependence on their CFC partnerships for 3 main reasons. The concept of community food centres is new, and only tested via CFCC's own pilot phase that took place in 2011/2012. Since the model has not been around for long enough to be challenged by macroenvironmental changes, there is an element of uncertainty as to how CFCC's management team will cooperate with its partners to react to large-scale issues. Due to high costs of developing the centres and implementing the model's programmes and services, each $\mathrm{CFC}$ project requires a significant financial investment from the CFCC. Although substantial due diligence is necessary before taking on a new partner and CFC project, thus providing evidence that there is a potential for a significant social return, the investment is required before any return can be obtained. What is more, CFCC faces the risk that a given partner organisation will not be able to raise the funds required to fund their side of the deal. The branding requirements that CFCC imposes are relatively flexible to allow each partner organisation's individual brand and reputation to be highlighted as well. These factors, coupled with decentralised marketing campaigns and obligations, may lead to marketing inconsistencies, public confusion and negative impact on the reputation of the CFCC and community food centres.

Once committed to developing a CFC, partner organisations also face financial, operational and reputational risks. Consid- 
ering that a partner is expected to cover many start-up and operational expenses, the failure to do so in a timely manner could result in the delay of operations, a coinciding increase of overall costs and loss of reputation. The ability to provide a sustainable resource plan is a deciding factor as to if CFCC will enter the partnership. The newness of the CFC model also implies that partner organisations face the risk of lack of control and certainty as to how the future will play out in terms of economic or political developments.

All in all, however, that risk is largely mitigated due to CFCC's intensive selection process and its commitment to and expectations of collaboration and communication. Benefits to both parties include the prospective ability to achieve economies of scale for a social purpose, and gain the knowledge that is shared through CFCC's extensive network of socially-oriented organisations and individuals. The community of interests also shares the added benefit of receiving a model and programmes that are tailored to the context and circumstances that they exist in; a fundamental advantage of partnership with CFCC is that an organisation can leverage the experience and knowledge of its management to solve community health, food, and social issues.

\section{CAP-Märkte - supermarket}

Another example of a social purpose franchise company is a supermarket chain. One of these companies is CAP-Märkte, a chain of supermarkets that operates as a social franchise company with the key goal of providing jobs to the disabled while doing so in a profitable manner. The first store was opened in Germany in 1999 by GDW Sud, a charitable cooperative organisation formed for the benefit of the disabled, and has expanded to over 72 shops till its 10-year anniversary and over 100 locations in 2013, on the territory of Germany. The brand was named "CAP," based on the suffix of the word "handicap". Its social mission is providing careers to the disabled. Not only does it provide them with a steady income and a stable career path, which may be difficult for most to attain, but it also helps them reintegrate with society due to their social interactions with customers. Those with disabilities may have difficulties leading normal lives, yet CAP- Märkte gives them an opportunity to become reintegrated as members of society, and provides them with a sense of belonging to the community.

An employee statistic in 2006 demonstrates that the company hired 420 employees; of that number, approximately $65 \%$ of were considered disabled. By 2013, CAP Märkte had a total of 1257 employees with 713 jobs created for disabled people (CAP; Bartilsson, 2012). With such a high percentage of job positions dedicated to employees that can be classified as disabled, it was possible to see the company's value in following its social mission. Although some positions include operations, assembly, and logistics and are done away from public view, the positions held by the handicapped employees include primarily retailing and customer service. This allows the employees to enter into direct contact with the general population, and is beneficial to the handicapped employees.

Recently, this chain has expanded to numerous locations throughout the country due to a franchise model that has allowed the company to experience fast growth over the past two decades. The franchise allows for rapid expansion into key markets, particularly those that express a demand for a nearby supermarket. By franchising out, the company is able to increase a number of store locations and consequently improve brand awareness.

A key indicator in the company's ability to expand and sustain profitability lies in the many benefits for the company that come with employing the handicapped. For many stakeholders, from its employees to its customers, the supermarket chain can accommodate benefits that include providing employment to those in need, reducing greenhouse gas emissions (by setting up locations in secluded areas to allow a walking distance to the store), stimulating the local economy, and, all in all, providing groceries for the community. In doing so, this business model obtains support both from the local government, by providing equal employment opportunities, and the local community, by stimulating local area economic growth and regeneration when another retailer closes.

Financial benefits of employing "severely disabled" people allow the company to meet specific quotas standardized 
by the country's business laws and regulations. Firms that do not achieve these quotas are forced to pay a compensation fee to make up for lower productivity of disabled workers, which results in the necessity to hire more employees. This compensation fund is allocated to firms and organisations with integrational purposes, which means that CAP franchisees can receive additional funds from the government. Adding to this benefit, the cost of opening a new store can be minimized by the government which will financially support firms that support creating new job positions for the disabled.

Furthermore, this business model offers many advantages such as friendly customer service, a full array of products offering customers variety and convenience. Moreover, customer loyalty is augmented through the company's loyalty programme that rewards individuals who often shop at the supermarket. However, some disadvantages of this business model include inefficiency of disabled employees. Although the company will be compensated for employing the 'severely disabled', as previously mentioned, it still has a negative impact on its operational efficiency. The need to increase the workforce to compensate for this lack of effectiveness may jeopardise the overall profitability by increased wage costs of the company. This may also translate into increased training costs for new workers, as it may be more challenging and take more resources to train a learning-impaired person. Taking into account a social perspective and disability acceptance, it is fundamental that other employees should able to respect and understand the disabilities their co-workers may have. It goes without saying that social implications that resurface must be addressed if any issues arise. Acceptance must be universal within the store model and other employees must tolerate co-worker's limitations.

For the franchisee, the key benefit of purchasing a franchise is the ability to hold a stake in a well-known and proven company that is recognised by the local population. The customer loyalty programme will attract returning customers, and the cost of advertising can also be reduced. Additionally, the franchisee will receive aid from the parent company which holds several years of experience in the grocery sector. To help new franchisees, the parent company develops a new business plan for each market.
Its extensive experience can translate into highly accurate information used for analysis and financial speculation. One example of franchisor support includes support through data and benchmarks that have been accumulated over the years of management activities. A given franchisee can juxtapose this information with their own store to compare operational efficiency relating to other locations.

No financial support is provided when opening a CAP store. However, a proven track record of success and profitability allows potential investors to increase confidence in the offered business model. There is an initial franchising fee for the company, paid in two separate instalments. This is soon followed by a levy of $0.6 \%$ on turnover for support and $0.1 \%$ on advertisement. In the initial period, the franchisor provides support to their franchisees, in terms of lease negotiations, setting up a shop, and monthly advisor visits. The first two weeks after opening are considered crucial for the store as that time creates a first impression and may ultimately determine whether someone becomes a returning customer or chooses another company for their local grocery needs. By and large, the initial customer retention can correlate with future sales and outcomes. Therefore, the franchisor provides strong support in this period to ensure future success. They do so by supplementing new stores with additional staff to maximize customer service. Advice is also provided in the beginning so that new store owners avoid making mistakes that were made in the past. Furthermore, the training support allows franchisees to optimize recruitment procedures as well as train their own employees for specific tasks, including stock inventory and ensuring quality in the workplace.

To preserve the CAP brand name, both the franchisor and the franchisee should make quality their priority. To maintain such a high level of quality, regular visits are made to individual stores to both inspect operational functioning and to provide feedback on areas that need improvement. An annual meeting between store operators and the core company management is held each year to ensure unity between the company and its brand locations.

Although financial information is kept private from the public due to intense competition in the industry, studying success- 
ful new branch openings each year, one can conclude that this may be a profitable franchise to hold for a potential franchisee. Not only do government rules and regulations have a positive impact on the company's profit (as explained by the "severely disabled" financial benefit laws) but the combination of strategic location base, the franchisor's aid, and decades of operational data shall relieve an investor of investment risk. Additionally, despite lower efficiency of disabled employees, the company has continued to maintain profitability and rapid expansion year to year, demonstrating a profitable business structure. These factors prove that the franchise in question is a low-risk venture.

In conclusion, CAP-Märkte can successively distinguish itself as a social franchise through its business model and concept that provide its stakeholders with many benefits, including employees, community, local government, and investors. Due to its unique characteristics of providing careers to the disabled and its ability to generate a profitable return to its investors, this company holds many values and can be viewed as a potential business perspective.

\section{Conclusion and findings}

The interest in social franchising is gaining momentum around the world as it may be structured in many different ways, including sole proprietors, for-profit and non-profit firms, non-governmental organisations, youth groups, community organisations, and more. It is worth mentioning that social franchise operates both in the non-profit sector and the commercial one.

Findings show that the franchise model can be translated and transformed into social attitude. It can be implemented in many different areas, using a commercial method of doing business to build socially sustainable societies. The cases differ in terms of geographical location and the character of undertaken business. Moreover, the social franchise model may help to resolve the problem of social exclusion. The study shows that the social franchising model can be successfully applied in different dimensions of social entrepreneurship.

The abovementioned case studies are well established social enterprises which use the franchise business model to develop, replicate and scale up business. Similari- ties can be seen between commercial and social franchising. Social ventures use the framework of commercial franchising to generate social profit. It is worth mentioning that franchising is a successful strategy of systematic replication in the commercial sector and it entails an effective concept that has been tried and tested, being implemented by largely independent franchisees at other locations within a common framework and supported by a contractual agreement. There is potential for adapting franchising to social environment. Moreover, the social franchise business model is a useful tool to scale up social venture and exercise influence on social value creation.

This study provides foundational findings for future research in the nascent area of social franchising. Further research is needed to discern better possibilities for social franchising, to create an opportunity to solve social problems and encourage disadvantaged people to be active in the field of entrepreneurship, to analyse which forms of social franchises as entrepreneurship forms are implemented on the market as well as to understand the risks and benefits of social franchising for participants in different contexts.

\section{Endnotes}

1 Following terms were used simultaneously to referee to social enterprise in the text: social entrepreneurship, non-profit, social venture.

\section{References}

Bartilsson, S. (2012). Social franchising - Obtaining higher returns from investments for jobs in social enterprises, European Social Franchising Network, http://www.socialfranchising.coop/uploaded/ Report\%20Social\%20Franchising\%20120524.pdf (30.01.2017).

Beckmann, M. and Zeyen, A. (2014). Franchising as a strategy for combining small and large group advantages (logics) in social entrepreneurship: A Hayekian perspective. Nonprofit and Voluntary Sector Quarterly, 43(3), 502-522.

Braun, J. and Lotter, D. (2004). Franchising im Stiftungswesen. Stiftung\&Sponsoring, 6 .

CAP Market, http://www.cap-markt.de/aktionen/2016.html (30.01.2017).

Cook, B. (2012). Social franchising: How do you do it and what are the benefits? https://www.theguardian.com/social-enterprise-network/2012/nov/06/ social-franchising-how-what- benefits (11.01.2017) 
Community Food Centres Canada, Neighbour 2 Neighbour Centre. Neighbour to Neighbour Centre (Hamilton), http://www.n2ncentre.com/communityfoodcentre (2.12.2016).

Community Food Centers Canada, https://cfccanada.ca/news/food-community-change-our-2015annual-report (22.02.2017).

Du Toit, A. (2014). Social Franchising as Organizational Format - An Overview. In: I. Alon (ed.), Social Franchising. Palgrave Macmillan, DOI:10.1057/9781137455840.0005

European Social Franchising Network (2011). Putting People Before Profit. http://www.socialfranchising.coop/uploaded/CASA $\% 20$ Case $\% 20$ Study\%20240811(1).pdf (accessed 20.01.2017).

Lyon, F. and Fernandez, H. (2012). Strategies for scaling up social enterprise: lessons from early years providers. Social Enterprise Journal, 8(1), 63-77, DOI:10.1108/17508611211226593.

Schuhen, A. (2004). Franchising: ein Modell für den Nonprofit-Sektor? In: H. Kötz, P. Rawert,
K. Schmidt and W.R. Walz (eds.), Non Profit Law Yearbook 2003. Köln: Carl Heymanns Verlag.

Smith, E. (2002). Social franchising reproductive health services. Can it work? A review of the experience. Marie Stopes International Working Papers, no. 5 , February.

The Guardian (2016). Which country has the world's best healthcare system? https://www.theguardian.com/society/2016/feb/09/which-countryhas-worlds-best-healthcare- system-this-is-the-nhs (11.01.2017).

Tracey, P. and Jarvis, O. (2007). Towards a theory of social venture franchising. Journal of Entrepreneurship: Theory and Practice, 31(5), 667-685, DOI:10.1111/j.1540-6520.2007.00194.x.

Volery, T. and Hackl, V. (2010). The promise of social franchising as a model to achieve social goals; Handbook of research on social entrepreneurship, DOI:10.4337/9781849804684.00015.

Yin, R.K. (2003). Case Study Research: Design and Methods. Thousand Oaks, CA: Sage Publications. 